\title{
Organisaatioiden muutos- ja kehittämisprosessit - luonne ja dynamiikka
}

\author{
Asko Miettinen
}

\author{
Organisaatioissa on "löydetty" rakenteiden jälkeen \\ prosessit. Näkökulman muuttaminen perinteisiä \\ vertikaalisia ja hierarkkisia rakenteita korostavasta \\ lähestymistavasta horisontaalisiin prosesseihin on \\ auttanut ratkaisemaan joitakin organisoinnin pulmia \\ - ja näyttää tuoneen mukanaan joukon uusia. \\ Käytännössä on todettu prosessien kehittämisen ja \\ uudistamisen monimutkaisuus ja monimuotoisuus. \\ Onko prosessien luonteesta ja dynamiikasta \\ avautunut vain osa?
}

Prosessin käsitteen ymmärtäminen on keskeistä sekä konsultoinnille, prosessien tutkimukselle että käytännön liikkeenjohdolle. Laajasti ymmärrettynä prosessi viittaa siihen, miten asioita tehdään pikemminkin kuin mitä tehdään. Myös käytännön toiminnassa puututaan useammin siihen, miten asioita hoidetaan kuin mitä tehdään. (Schein 1969 ja 1987) Itse asiassa tehtävärakenteen ja prosessin välinen eroa voidaan pitää sopimuksenvaraisena: rakenne on prosessin laajentuma, joka viittaa stabiileihin ja toistuviin, kussakin tapauksessa rakenteiksi nimettyihin prosesseihin.

Prosesseille on ominaista yksilöllisten tai kollektiivisten tapausten ja toimintojen peräkkäisyys, sekvenssi. Ne "avautuvat" tai ilmenevät ajassa ja erilaisissa yhteyksissä ja kuvaavat usein jonkin muutosta ajassa. Prosesseihin liitetään olettamus siitä, että todellisuus ei ole vakaa tila, vaan ensisijaiselta luonteeltaan dynaaminen prosessi. Tällöin on kysymys sosiaalisesta todellisuudesta, joka "pikemminkin esiintyy kuin on olemassa". (Sztompka 1991) Analyyttisessä mielessä prosesseja voidaan pitää myös käsitteellisinä kategorioina ja kausaalisuhteiden tulkitsemisessa ja selittämisessä käytettynä logiikkana.

Toimijat aktivoivat prosesseja, mutta niitä ei kuitenkaan voi jäännöksettömästi selittää viittaamalla yksilöllisiin tai kollektiivisiin toimijoihin. Toiminnot rakentuvat aina erityisissä yhteyksissä, konteksteissa. Tämä toimijoiden ja kontekstin kaksinaisuus on aina otettava huomioon toisaalta prosesseja täsmentävänä ja toisaalta informaatiota ja 


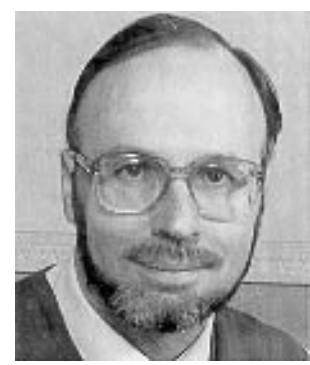

Asko Miettinen

vaikuttamismahdollisuuksia rajoittavana tekijänä. Prosesseja täsmentävät kontekstit muovaavat ja niitä muovataan. Myös toimijoilla on dualistinen rooli: he ovat tuottajia mutta myös tuotteita. Konteksti ei ole vain yllykeympäristö, vaan edustaa sisäkkäisten rakenteiden ja prosessien järjestelyä, jossa "havaitsevien, oppivien ja muistavien toimijoiden subjektiiviset tulkinnat auttavat muovaamaan prosessia”. (Levitt \& March 1988; Huber 1991) Prosessuaaliset peräkkäisyydet paikantuvat ja prosesseilla on myös niille ominainen tapahtumisen rytmi.

Ajallinen dimensio on prosessien keskeinen ulottuvuus. (Hassard 1991) Se kytkee prosessin syntyvään tulokseen tai tuotokseen. Menneisyys ja historia muovaavat aina jonkiasteisesti esiintyöntyvää tulevaisuutta. Mitä tapahtuu, miten tapahtuu, miksi tapahtuu ja mitä syntyy tuloksena kaikkiin näihin kysymyksiin sisältyy myös ajallinen näkökulma, ne ilmentävät riippuvuutta siitä, milloin tapahtuu. Aikaulottuvuuden merkitystä korostaa myös se, että nykyiset työorganisaatiot rakentuvat pitkälle työtehtävien ajallisten vaatimusten mukaan.

$\mathrm{P}$ rosessien luonne voi olla moninainen: ne voivat olla lineaarisia, suunnattuja, kumulatiivisia, palautumattomia - tai sitten ei-lineaarisia, radikaaleja ja transformatiivisia. Prosessien analysoijan on oltava avoin monille vaihtoehdoille ja mahdollisuuksille. Prosessien kuvaamisesta pitäisi edetä erittelyihin, malleihin, käsitteellistämiseen, mittaamiseen, mekanismeihin ja selittämiseen. Erityisen tärkeää on niiden mekanismien selittäminen, käynnistävät ja ylläpitävät prosessia. Tällaiset mekanismit voivat olla suoraan havainnoitavissa tai välittyä avaintoimijoiden tietoisten

pyrkimysten kautta. Ne voivat edustaa myös välittömän tai etäisen kontekstin erilaisia piirteitä. Tapahtumat ja aikajärjestykset ovat prosessien rakennusaineksia - välttämättömiä tuntea, mutta eivät aina riittäviä prosessien mekanismien ymmärtämiseksi.

Pettigrew (1997, 340) on esittänyt joukon olettamuksia siitä, millaisia kysymyksiä prosessien analysoijan kannattaa ottaa huomioon selittääkseen prosessin, sen kontekstin ja tuotosten yhteyksiä:

1. Prosessin analyysin monitasoisuus

2. Ajalliset liittymät: mennyt, nykyinen ja tuleva 3. Selityksen merkitys toiminnalle ja kontekstille 4. Prosessin pikemmin holistinen kuin lineaarinen tutkiminen

5. Tarve yhdistää prosessianalyysi tuotosten paikantumiseen ja selitykseen.

Pettigrew viittaa sisäisen kontekstin ("organisaation sisäinen mosaiikki”) ja ulkoisen kontekstin (rakenteellinen, kulttuurinen ja poliittinen) prosessin piirteitä muovaavaan vaikutukseen. Näiden luoma epävarmuuden aste ja edellytettävien päätösten ja ratkaisujen kiireisyys saattaa myös vaihdella ajankohdasta toiseen, kuten Tichy (1984) on osoittanut. Prosessien tutkiminen on siten monimuotoisuudessaan työlästä "käsityötä", johon liittyy harkittujen arvioiden ja ratkaisujen lisäksi myös intuitiota ja hiljaista tietoa. Pettigrew onkin kuvannut prosessitutkimusta deduktion ja induktion vaihtelevina sykleinä, joissa analyysin eri tasot ja niiden väliset yhteydet saattavat avautua vasta vuosien kuluttua. (Pettigrew 1997)

\section{PROSESSINÄKÖKULMAN NOUSU}

$\mathrm{O}$ n helppo ymmärtää, miksi prosessijohtaminen ja prosessien kehittäminen ovat herättäneet niin voimakasta vastakaikua organisaatioiden avainhenkilöissä. Monet organisaatiot ovat edelleen korostuneen funktionaalisia ja hierarkkisia. Niiden toiminta kärsii kroonisesti huonosta koordinaatiosta ja rajoittuneesta sivusuuntaisesta kommunikaatiosta. Työkokonaisuudet ovat monesti pilkkoutuneet tai hajautettu useiden yk- 
siköiden toteutettavaksi, mikä vaikeuttaa niiden sujuvaa suorittamista. Funktionaalisissa yksiköissä korostuvat myös helposti samoja tehtäviä tekevien ihmisten samansuuntaiset intressit ja yhteisyys, mikä sekin saattaa hankaloittaa yksikön rajojen yli käyviä toimintoja.

Prosessit näyttävät siten tarjoavan uuden näkökulman tai viitekehyksen tai muodostavan lupaavan ratkaisun organisaation kehittäjien ja tutkijoiden ongelmiin. Näkökulma ei sinänsä ole aivan uusi, vaan organisaatioiden analyyseissa on perinteisesti käytetty jakoa esimerkiksi rakenteisiin ja prosesseihin, tuotekehittämistyössä puhuttu tuote- ja prosessi-innovaatioista jne.

$\mathrm{P}$ rosessinäkökulman vahva nousu sijoittuu erityisesti 1990-luvun alkuun. Kysymys on sekä eräiden vaikutusvaltaisten johtamissuuntausten ja tuotantotoiminnan menettelytapojen "koulukuntaistumisesta" että niiden ideologisista perusteista. Nämä voidaan väljästi sijoittaa prosessijohtamisen tai -ohjauksen kattokäsitteen alle. (Esim. Hannus 1994; Micklethwait \& Woolridge 1996; Tikkanen 1997; Alasoini 1998) Tyhjästä nämä näkökulmat eivät kuitenkaan ole syntyneet, vaan niiden taustalta löytyy sukupuu, joiden varhaisempia vuosirenkaita edustavat esimerkiksi teollisuudessa hyvin tunnetut laadunvalvontakehitelmät, "juuri oikeaan aikaan"-ajattelu, kevyt (lean) tuotantomalli, toimintojohtaminen (Activity Based Management, ABM) ja aikaan perustuva johtaminen (Time Based Management"). Nämä kaikki heijastavat ajattelullista murrosta, jossa organisaatiot on vähitellen ruvettu näkemään pikemminkin "dynaamisten prosessien portofolioina kuin staattisten roolien hierarkkiana" (Ghosal \& Barlett 1995).

$\mathrm{L}$ iiketoimintaprosessien radikaali uudelleen Suunnittelu (Business Process ReEngineERING, BPR) ja laatujohtaminen (Total Quality Management, TQM) ovat kuluvan vuosikymmenen aikana käytetyimpiä organisaatioiden uudistamiseen sovellettuja lähestymistapoja. Näistä kahdesta liiketoimintaprosessien uudistaminen on kohdannut muotivillityksen tyypillisen kehityskaaren: ensin tavaton innostus ja laaja suosio (jopa 70-80 prosenttia johtavista yrityksistä raportoi hyödyntä- vänsä sitä), sitten kritiikin kasvaminen sekä menetelmän rajoitusten esillenostaminen ja innostuksen tasaantuminen. Siitä huolimatta, että tutkimusten mukaan jopa 70-75 prosenttia liiketoimintaprosessien uudistamisohjelmista on arvioitu epäonnistuneiksi (esimerkiksi Grint \& Case 1998) on niiden soveltaminen edelleen varsin laajaa. Hyödyntäjät ovat ensi-innostuksen jälkeen tuoneet esille $\mathrm{mm}$. työilmapiirin heikentymiseen, luovuuden vähenemiseen, luottamuksen heikkenemiseen ja tiimityön vaikeutumiseen viittaavia vaikutuksia.

Toisaalta on otettava huomioon, että kysymyksessä eivät ole tarkkaan rajatut tai paketoidut toimintatavat, vaan väljähkösti määritellyt periaatteet ja tekniikat, joiden paikalliset sovellutukset saattavat vaihdella syvyydeltään ja laajuudeltaan melkoisesti. Onnistuneitakin kehittämisprojekteja on lukuisasti ja niiden hyötyvaikutukset ovat olleet merkittäviä, osin tuloksiltaan dramaattisen hyviäkin asetettujen tavoitteiden saavuttamisessa, ns."kriittisten suoritusmittareiden" (Hammer \& Champy 1993), kuten kustannuksissa, laadussa ja palvelunopeuden paranemisessa.

Laatujohtamisen periaatteet ja kehitystavoitteet eivät ole niin dramaattisia kuin liiketoimintaprosessien radikaalissa uudelleensuunnittelussa. Laatujohtamiseen kytketään usein sekä pitkäjännitteisyys että jatkuvan kehittäminen, usein "pienten askelten tienä". Yhteisiäkin tavoitteita on, kuten asiakasohjautuvuuden ja sitoutumisen korostaminen.

BPR-ajattelua on kritisoitu voimakkaasti huomion kiinnittämisestä liian kapeasti vain toimintaprosessien tehokkuuden ylivertaistamiseen kustannuksia alentamalla, "kaikki löysät pois"-ideologiasta. Ylivertainen operatiivinen tehokkuus ei välttämättä johda pitkällä aikavälillä menestykselliseen toimintaan ja pysyvän kilpailuedun saavuttamiseen. Näin suunnattu kehittämistyö voi toki saada aikaan parannuksia alueilla, joilla ollaan eniten muista jäljessä, mutta se ei välttämättä hyödytä pitemmän aikavälin strategista ajattelua, ellei parannusten vapauttamia voimavaroja käytetä myös uuden toiminnan kehittämiseen ja innovaatioihin. Esimerkiksi Hamel ja Prahalad (1994) 
ovat arvostelleet BPR-ajattelua siitä, että se on vahvistanut ns. "nimittäjä-johtamista" - panostekijää (nimittäjää) vähimmäistävää suuntausta työvoimaa ja kustannuksia karsimalla pystymättä kasvattamaan tuotosta (osoittajaa) kehittämällä uusia toimintaideoita ja siirtymällä uusille tuotemarkkinoille. Samantapaista kritiikkiä liiallista operatiiviseen tehokkuuteen keskittymistä kohtaan on esittänyt Porter (1996). Kysymyksessä on eräänlainen universaalisuusajattelun muoto: miksi kaikkien pitäisi toimia samalla tavalla - paremman ja tehokkaamman tulisi myös joskus voida muuttua erilaiseksi. BPR-hankkeiden työllisyyssisällöllisiä seuraamuksia on näinollen problematisoitu monesta suunnasta.

\section{Organisaatioteoriassaonpitkään tunnettujatunnustettu ns. organisatorisen liikkumavaran(slack)merkitys toiminnanuudistamiselle. Semääritelläänolemassaole- vanhenkilöstömääränjasenhenkilömääränerotukseksi, jokajuuri rïttäänykyisen toiminnanpyörittämiseen. Uusiutuminenjakehittyminenedellyttävätyleensä positiivistaerotustaensinmainitunjavïmeksimainitun henkilöstömääränvälillä.}

Liiketoimintaprosessien radikaalien uudistamisprojektien onnistumista on tutkittu myös suurissa suomalaisissa yrityksissä. (S.A.M.I. Ernst \& Young 1998) Käytetyn typologian mukaan suurin osa tutkituista kehittämishankkeista oli uudistumisasteeltaan "alhaisia" eli keskittyi kapehkoihin automatisointi- ja operatiivisiin kehittämistehtäviin. Laaja-alaisia, strategisiin hankkeisiin liittyviä uudistamishankkeita oli vähän. Yleistäen voidaan todeta, että rajatut operatiiviset kehittämisprojektit hallitaan paremmin kuin strategisiin tavoitteisiin pyrkivät uudistamisohjelmat, jotka epäonnistuivat usein. Yhteisenä tekijänä tuli esiin muuallakin tärkeäksi osoittautunut tietotekniikan tärkeys uudistamisessa. Suomalaisten kehittämisprojektien onnistumisprosentti oli korkeampi (noin puolet) kuin vastaavissa ulkomaisissa hankkeissa, mutta ne olivat toisaalta suhteellisen kapea-alaisia. Epäonnistumisen syynä oli yleensä toteuttamistapa.

$\mathrm{T}$ aukukossa 1. on yhteenvedonomaisesti verrattu toisiinsa kahta johtavaa prosessijohtamisen näkökulmaa, BPR-ajattelua ja laatujohta- mista. Niiden rinnalle on nostettu huomattavasti aiemmin, 1940-luvun lopulla kehitetty lähestymistapa, ns. sosiotekninen koulukunta.

\section{PROSESSIN METAFORAT JA RETORIIKKA}

Prosessien esiinsaaminen ja kehittäminen edellyttävät prosessisanastoa. Tällainen sanasto on luonteeltaan aktiivista: esimerkiksi joksikin tulemista, ilmaantumista, kehitystä, muuntumista ja hajoamista. Metaforat voivat toimia oppimisen välineinä erityisesti silloin, jos järki, perinteet ja tavanomainen logiikka ja rationaalisuus toimivat rajoittavina tekijöinä. Samalla tavoin oppimista ja oivalluksia voi edesauttaa pikemminkin tarinoiden kuin erillisten tapahtumien kertomisella ja prosessien luonnetta voidaan kuvata paremmin filmin kuin tuokiokuvan avulla. Käytetty kieli voi olla staattisten määritelmien kahlitsemaa, muodostaa "analyyttisen vankilan". Kielikuvien artikuloinnin merkitys on käynyt ilmi esim. muodikkaiksi käyneiden missioiden ja visioiden viestittämisessä organisaation henkilöstölle. (esim. Collins \& Porras 1994) Ne tarjoavat parhaimmillaan innostavan samastumiskohteen ja energisoivat henkilöstöä ponnisteluissa yhteisesti jaettuihin päämääriin ja tavoitteisiin.
Prosessillesopivanakielikuvanavoidaanpitääjokisuis- toa,jossaon useitatoisïnsa virtaaviajatoisistaan rïppuvaisiahaarakkeita,joillakaikillaonvaikutuksensa virtausvoimanylläpitämisessä. Nemuotoilevatmaastoa jamaastopuolestaanmuotoileeniitä. Samaantapaan vuorovaikunteistenvoimiendynamiikkavaikuttaaproses- sïnjamuovaasen luonnettajalopputulosta.

Metaforia ja tietoista tai tiedostamatonta retoriikkaa on pyritty hyödyntämään muutoksien läpiviemisen nopeuttamiseksi. Myös uusien "ismien" kuten liiketoimintaprosessien radikaalin uudelleensuunnittelun retoriikkaa ja sen funktiota on eritelty. Esimerkiksi englantilaiset Grint ja Case (1998) ovat kritisoineet voimakkaasti BPR "sotaisaa" kieltä, analysoineet sen synnyn kulttuurihistoriallista taustaa ja kontekstia. He näkevät BPR:n amerikkalaisen liikkeenjohdollisen diskurssin "vastakolonialisaationa”, hyökkäyksenä painoarvoltaan uhkaavaksi kasvavan japanilaisen ajattelun ja joh- 
Taulukko 1. Liiketoimintaprosessien uudistamisen, laatujohtamisen ja sosioteknisen koulukunnan vertailu (Mumford 1997, 230-231).

\section{Liiketoimintaprosessien Laatujohtaminen Sosiotekninen koulukunta uudistaminen}

\begin{tabular}{|c|c|c|c|}
\hline Filosofia & Vallankumouksellinen & $\begin{array}{l}\text { Jatkuva parantaminen } \\
\text { muutos }\end{array}$ & $\begin{array}{l}\text { Ihmisten ja teknologian } \\
\text { välisen suhteen optimointi }\end{array}$ \\
\hline $\begin{array}{l}\text { Ensisijaiset } \\
\text { tavoitteet }\end{array}$ & $\begin{array}{l}\text { Suoritusten parantaminen } \\
\text { vanhoja funktionaalisia ra- } \\
\text { joja muuttamalla, nopeu- } \\
\text { den ja laadun kehittämi- } \\
\text { nen }\end{array}$ & $\begin{array}{l}\text { Asiakkaan tarpeiden } \\
\text { - tyydyttäminen. Asiak- } \\
\text { kaiden tarpeet tyydyttä- } \\
\text { vien prosessien ja tuot- } \\
\text { teiden aikaansaaminen }\end{array}$ & $\begin{array}{l}\text { Korkean suoristustason } \\
\text { organisaatio ja laadullisesti } \\
\text { korkeatasoisen työympä- } \\
\text { ristön luominen }\end{array}$ \\
\hline $\begin{array}{l}\text { Muutos- } \\
\text { ärsyke }\end{array}$ & $\begin{array}{l}\text { Ympäristö - kilpailun } \\
\text { kiristyminen }\end{array}$ & Asiakkaan vaatimukset & $\begin{array}{l}\text { Ympäristön tekijät, asiakkaat, } \\
\text { kilpailu, yhteisö }\end{array}$ \\
\hline
\end{tabular}

\section{Työprosessit}

Informaatioteknologian kehittäminen. Ympäristöstä saatavan relevantin informaation ja koordinaation parantaminen. Painotus kilpailuaseman parantamisessa merkittävillä muutoksilla.

\section{Organisaatio-}

rakenteet

Uusi rakenne luodaan prosessien tutkimisen ja kultakin odotettavien tulosten mukaan. Muutokset saatetaan perustaa insinööritaitoihin. Kehittämisen tuloksena pitäisi syntyä sitoutumista ja ammattiylpeyttä. Työperustuu monitaitoisiin tiimeihin.

Normit

Suurien muutosten hyväksyminen

Anot

Työprosessien kehittä- Sosiaaliset, organisatoriset minen paremman laa- ja tekniset ratkaisut dun varmistamiseksi. Painotus jatkuvassa prosessien kehittämisessä. tarkoituksena kaikkien kolmen optimoiminen. Painotus organisatorisessa uudistumisessa.

Rakenne säilyy byrokraattisena. Painotus ei ole järjestelmän kokonaisuudessa, vaan asiakassuhteissa. Työtehtäviin ja rooleihin sisältyy laatuvastuuta. Johto edellyttää sitoutumistaa laatuun. Tavanomaiset työnjohdolliset roolit säilyvät.

Laadun kehittämiseen osallistuminen.

Innovaatiot. Tiimityö. osallistuminen. Tiimityö Järjestys. Erinomaisuus. ja sitoutuminen. Joustavuus.

Ihmisten ja koneiden tehokas käyttö.

Rakenne on joustava. Päätökset tehdään siellä, missä ongelmia ilmenee. Rajaongelmiin kiinnitetään huomiota. Organisaatio suunnitellaan synnyttämään sitoutumista ja ammattiylpeyttä. Parantunut työelämän laatu on yksi tulos. Työtehtävät suunnitellaan monitaitoisuutta sisältäviksi.

Useimpiin työtä koskeviin kehittämisasioihin

Korkea laatu 
tamiskäytäntöjen valta-asemaa vastaan. BPR sisältää heidän mukaansa sekä japanilaisilta omaksuttuja elementtejä että heitä vastaan kapinoivia aineksia. Sen kehittämässä retoriikassa ja propagandassa on alusta saakka korostettu vallankumouksellisuutta: vanhat tuotantomenetelmät, liikkeenjohdolliset tekniikat ja organisaatiomuodot on nihilistisesti tuomittava. (Grint \& Case 1998, 564)

$\mathrm{N}_{\mathrm{i}}$ orjalainen Finstad (1998) on analysoinut ulkishallinnollisten organisaatioiden käyttämää muutosretoriikkaa. Hänen mielestään muutoksen retoriikka on ennen kaikkea muutosprosessia määrittelevä symbolinen ilmaus. Finstadin mukaan suuri osa julkisen hallinnon uudistamistyöstä voidaan nähdä rationaalisesti suunniteltu- avoin areena, jossa kumpaakin liittyviä symbolisia ilmauksia voidaan esittää ja kuunnella, käydä dialogia niiden välillä. Muutosprosessin suuntaa määrittää Finstadin mukaan ennen kaikkea näiden kahden rationaliteetin ja niiden retoristen ilmaisujen välinen voimatasapaino.

$\mathrm{M}$ etaforia käytetään muutosprosesseissa ymmärryksen edistämiseen kytkeytyvinä "työkaluina”. Ne voivat välittää sekä muutosagentille että muille muutosprosessissa mukanaoleville arvioita tilanteesta, antaa vihjeitä siitä, kuinka asiat ymmärretään ja kuinka niihin voi yrittää vaikuttaa.

Marshak (1993) on esittänyt joukon käytännön-

Taulukko 2. Muutosprosesseihin ja muutosagentin tehtäviin liittyviä kielikuvia. (mukaillen: Marshak 1993)

Muutoksen ominaisluonne Mutosagentin ominaisluonne

Korjaminen ja huolto

Rakentaminen ja kehittäminen

Uudelleen kohdentaminen

Vapauttaminen ja uudelleen luominen
Korjaaja, 'tinuri', sopeuttaja, virittäjä; hoitaa sitä mikä on rikki; oikeiden työkalujen tarjoaminen; oikean työkalupakin hyödyntäminen

Lisääminen, kasvattaminen, vahvan perustan rakentaminen; kouluttaminen, nopeuttaminen

Siirtyminen eteenpäin, siirtyminen a:sta b:hen, jonkin taakse jättäminen, esteiden ja aikataulujen tarkkaileminen, välitavoitteiden asettaminen, kehitysportaiden hahmottaminen

Herättäminen, laaja-alainen ajattelu, uuden paradigman luominen (uusi tapa ajatella ja ymmärää), menneen kahleista murtautuminen, uuden keksiminen ja synnyttäminen na prosessina, joka kohdistuu toimintojen viralliseen puoleen, organisaation rationaalis-funktionaaliseen ytimeen. Tämän "monokraattisen rationaalisuuden" rinnalla toimii kuitenkin epävirallinen "käytännöllisen" rationaliteetin järjestelmä, joka liittyy ongelmanratkaisuun ja professionaaliseen ymmärtämiseen. Nämä kaksi rationaliteetin muotoa on pystyttävä yhdistämään luomalla läheisiä muutokseen ja sen kehittymiseen liittyviä kielikuvia. Niissä muutosagentin tehtävä ja rooli vaihtelevat muutoksen ominaisluonteesta riippuen seuraavasti:

$\mathrm{M}$ uutoskonsultin tehtävän kuvaamiseen käytetty kielikuvien kirjo on melkoinen: hän voi toimia katalysaattorina, prosessin helpottaja- 
na ja auttajana, "sparraajana”, ärsyttäjänä, ilmanpuhdistajana, keskustelukumppanina, kyseenalaistajana, unilukkarina, hukkuvan oljenkortena, voiteluaineena, syntipukkina, likaisen työn tekijänä, tulkkina jne. Tällaisten kielikuvien luomiseen ovat osallistuneet sekä konsultit itse että heidän asiakkaansa. Ne kuvaavat usein myös sitä kehitysvaihetta tai tilannetta, jossa konsultin ja asiakkaan yhteistyö tapahtuu.

Yhteistyöllä on oma kehityskaarensa ja -prosessinsa. Olennaisinta on kuitenkin toimivan yhteistyösuhteen rakentaminen ja säilyttäminen. Ulkopuolinen henkilö ei yleensä pysty pääsemään riittävän syvälle organisaation kulttuuriin ilman pitkäaikaista työskentelyä sen sisällä. Sen tähden useimmiten hänen ainoa mahdollisuutensa on avoimen ja luottamuksellisen yhteistyösuhteen luominen ja omien menetelmien sopeuttaminen joustavasti asiakasorganisaation tilanteen ja kulttuurin mukaan.

Eksplisiittisen retoriikan lisäksi myös nonverbaalisella kommunikaatiolla on merkitystä. Steele (1975) on analysoinut "symbolista vaatetusta", jonka konsultti pukee ylleen asiakastilanteita varten. Samanlaista symboliikkaa tarvitsevat organisaation edustajatkin muutosprosesseissa. Kysymys on symbolisesta samastumisesta, valtaeroista ja uskottavuudesta ja imagosta prosessia käynnistettäessä ja sen kestäessä. Yhdessä taiteilijansa kanssa Steele on rakentanut uskottavia ja paljon käytettyjä vaateparsia, kuten "auktoriteetti puhuu", "supertekninen asu”, ja "vain yksi meistä”. Odotukset ja aikaisemmat kokemukset yhteistyöstä saattavat pitkälle määrittää sitä, millainen symbolinen oheisviestintä toimii ja tukee varsinaista kehittämistyötä.

\section{Prosessikonsultointi, interventiot ja organisaation dynamiikka}

$\mathrm{P}$ erinteisiä organisaation konsultointimalleja voidaan kutsua ASIANTUNTIJAMALLIKSI jaLÄÄKÄRIPOTILAS -MALLIKSI. Edellisessä asiakas on muodostanut oman käsityksensä siitä, mikä hänen ongelmansa on, millaista apua hän tarvitsee ja kuka tuota apua tai siihen liittyvää informaatioita voi tarjota.

Toimiakseen hyvin nämä mallit edellyttävät sitä, että ongelma on oikein määritelty, konsultin kapasiteetti ja asiantuntemus on tunnistettu oikein, asiakas on kommunikoinut probleeman oikein ja että tarvittava asiantuntijatarve vastaa ongelman luonnetta. Edelleen asiakkaan täytyy käydä läpi ja hyväksyä yhteistyön mahdolliset seuraukset. Lääkäri-potilas -mallissa asiantuntijalle annetaan tämän lisäksi valtuudet tehdä diagnoosi. (Schein 1997, 22-29)

$\mathrm{P}$ rosessikonsultoinnin täydentää näitä perinteisiä laajasti käytössä oleva konsultointimalleja. Sen lähtökohtana on konsultin rakentama yhteistyösuhde eikä niinkään se, mitä asiakas tekee. Asiakas on kuitenkin ongelman omistaja konsultoinnin alusta sen päättymiseen saakka. Työtapaan ja perusolettamuksiin kuuluu, että asiakas saattaa tarvita apua ongelmansa diagnosoimiseen ja hyötyy diagnoosiprosessiin osallistumisesta. Lisäolettamuksena on, että asiakas pystyy oppimaan, kuinka diagnostisoida ja ratkaista omia ongelmia. Prosessikonsultointi koostuu sellaisista konsultin tukemista toimenpiteistä, jotka auttavat asiakasta havaitsemaan, ymmärtämään ja toimimaan niiden tapahtumien ja prosessien mukaan, jotka esiintyvät hänen ympäristössään.

D rosessikonsultaation perinteisiin malleihin tuo1 ma täydentävä lisä on usein organisaation eirationaalisen puolen ymmärtäminen. Irrationaalisilla ja tiedostamattomilla prosesseilla on yllättävän suuri merkitys organisaation toiminnassa. Rationaalisen organisaatiokäyttäytymisen mallit eivät läheskään aina toimi käytännössä riittävän hyvin eivätkä aina tuota pysyviä, pitkäaikaisia muutoksia organisaation toimintaan. Rationaalisten mallien soveltamisessakin on huomattava, että psykodynaamiset prosessit vaikuttavat konsultointityöhön, vaikka niiden piirissä ei työskenneltäisi.

Garvin (1998) on laatinut selkeän viitekehyksen organisatorisista prosesseista ja niiden erilaisista painotuksista (Taulukko 3). Hän jakaa organisatoriset prosessit kolmeen erilliseen, mutta toisiinsa liittyvään kategoriaan. Kukin niistä korostaa pro- 
sessien jotakin puolta ja sen niiden erityisiä piirteitä muita kahta kategoriaa enemmän.

$\mathrm{T}$ YÖPROSESSIEN perinne liittyy vahvasti teolliseen traditioon, työntutkimukseen ja tuotantomenetelmien kehittämiseen. Tämä kehittämistyö on kohdentunut ennen kaikkea ns. operatiivisiin ja hallinnollisiin (tai tuki-) prosesseihin. Uusien tuotteiden kehittäminen, valmistus ja logistiikka ovat esimerkkejä operatiivisista prosesseista. Strateginen suunnittelu, budjetointi ja työsuoritusten mittaaminen taas edustavat hallinnollisia prosesseja. Molemmat pyrkivät "muuttamaan syötteet tuotoksiksi". Molemmilla on alku ja loppu sekä rajat, jotka voidaan määritellä jokseenkin tarkasti ilman mainittavia päällekkäisyyksiä. Molemmilla on myös joko organisaation ulkoisia tai sisäisiä asiakkaita. Erona on tuotoksen luonne: operatiiviset prosessit tuottavat tyypillisesti tuotteita tai palveluja ulkoisille asiakkaille kun taas hallinnolliset prosessit tuottavat informaatiota ja suunnitelmia sisäisten asiakkaiden käyttöön.

Organisaatioissa tunnetaan yleensä parhaiten operatiiviset ja hallinnolliset prosessit. Monet käytössä olevista työprosesseista ovat saaneet kehittyä kaikessa rauhassa ilman rationaalisuutta ja systemaattista suunnittelua ja saattavat sen tähden olla tehottomia. Tämä selittää BPR:n ja TQM:n kaltaisten lähestymistapojen aiheuttamaa suurta innostusta. Työprosessien uudelleensuunnittelun kautta voidaan tehottomuudet saada häviämään ja synnyttää merkittäviä tulosparannuksia ja lisäarvoa.

$\mathrm{P}$ elkkä työn uudelleenstrukturointi ei kuitenkaan välttämättä riitä. Organisaation työjärjestelmän muutoksilla on vaikutuksia organisaatiomuotoon, palkitsemiskäytäntöihin, henkilöstön asenteisiin, työmoraaliin jne. Uusien menettelyjen on oltava paitsi hyviä, myös hyväksyttävissä. Hyvätkin uudistukset nostattavat usein vihamielisiä vastavoimia organisaatiossa ja estävät järkevien kehittämisprosessien onnistumista.

Käyttäytymisprosessien tausta on organisaatioteorioissa ja ryhmädynamiikassa. Käyttäytymisprosessit viittaavat syvään juurtuneisiin käyttäytymismalleihin, työn kognitiivisiin ja interpersoonallisiin näkökohtiin. Vallitsevat käyttäytymismallit heijastavat organisaatiolle tyypillisiä tapoja toimia ja olla vuorovaikutuksessa, kommunikoida, tehdä päätöksiä ja sille ominaisia tapoja oppia. Näihin prosesseihin liittyvät käyttäytymistavat on tavallisesti omaksuttu epävirallisesti sosialisaation ja työkokemuksen kautta, ei niinkään muodollisessa koulutuksessa.

Työprosessien uudistamishankkeiden yhteydessä kuvitellaan valitettavan usein, että käynnistettävä kehittämistyö muuttaa automaattisesti ihmisten käyttäytymisprosesseja. Näin ei kuitenkaan useinkaan tapahdu, vaan organisaation tyypilliseen tapaan tehdä päätöksiä, kommunikoida ja oppia on kiinnitettävä nimenomaista huomiota ja käytettävä asianmukaisia interventioita muutoksien aikaansaamiseksi.

$\mathrm{M}$ UUTOSPROSESSIEN juuret nousevat strategisen johtamisen, organisaatioteorian, sosiaalipsykolo- gian ja organisaatioiden evoluutioteorian piiristä. Ajallisesti peräkkäisinä tapahtumina ja toimintoina ilmenevät prosessit kuvaavat, kuinka yksilöt, ryhmät ja organisaatiot mukautuvat, kehittyvät ja kasvavat tai taantuvat. Useimmille muutosprosesseille on ominaista pitkäkestoisuus ja dynaamisuus. Ne saattavat avautua ymmärrettäviksi vasta sitten, kun prosessien taustalla olevat mallit ja logiikka hahmottuvat riittävässä määrin.

Muutosprosessit voivat edustaa "pienten mutaatioiden hiljaista virtaa" (Gersick 1991), vallankumouksellista muutosta (Tichy 1984) tai jotakin näiden kahden ääripään väliltä. Garvin jakaa muutosprosessit kahteen yleiskategoriaan: autonomisiin ja johdettuihin. Autonomisilla prosesseilla on oma sisäisestä dynamiikasta johtuva kehityskaarensa. Toiseen ryhmään kuuluvat esimerkiksi teknologisista muutoksista johtuvat vallankumoukselliset uudistamistarpeet. Esimerkiksi toimialan muutosvauhti ja kehitys voi olla paljon nopeampaa kuin sillä toimivien yksittäisten yritysten kehitystahti. Johdetut prosessit eivät esiinny luonnostaan, vaan ne täytyy luoda.

$\mathrm{O}$ n ilmeistä, että erilaisiin organisatorisiin prosesseihin erikoistuneilla tahoilla on jossain määrin erilainen kieli ja käsitteistö. Tähän tuo 
Taulukko 3. Organisatoriset prosessit. (Mukaillen: Garvin 1998, 41)

Työprosessit Käyttäytymisprosessit Mutosprosessit

$\begin{array}{llll}\text { Määritelmä } & \begin{array}{l}\text { Syötteet tuotoksiksi } \\ \text { muuntavat peräkkäi- } \\ \text { set toiminnot }\end{array} & \begin{array}{l}\text { Laajasti jaetut käyttäyty- } \\ \text { mismallit sekä toiminta- } \\ \text { ja vuorovaikutustavat }\end{array} & \begin{array}{l}\text { Ajassa esiintyvät } \\ \text { peräkkäiset tapahtumat }\end{array}\end{array}$

\begin{tabular}{llll} 
Merkitys ja & $\begin{array}{l}\text { Organisaation työn } \\
\text { tehtävä }\end{array}$ & $\begin{array}{l}\text { Muotoilla tapaa, jolla työ- } \\
\text { tä johdetaan vaikuttamalla } \\
\text { siihen, miten yksilöt ja } \\
\text { ryhmät käyttäytyvät }\end{array}$ & $\begin{array}{l}\text { Muttaa organisaation } \\
\text { järjestelmää, luonnetta }\end{array}$ \\
\hline
\end{tabular}
$\begin{array}{lll}\text { Tärkeimmät } & \begin{array}{l}\text { Operationaaliset ja } \\ \text { kategoriat }\end{array} & \begin{array}{l}\text { Yksilölliset ja yksilöiden } \\ \text { väliset }\end{array}\end{array}$
Autonomiset ja johdetut, inkrementaaliset ja vallankumoukselliset

\section{Esimerkkejä \\ Tuotekehittäminen, Päätöksenteko, kommuni- tilausten hoitaminen, organisaation oppiminen strateginen suunnit- \\ Luominen. kasvu, trans- formatiivinen muutos. telu taantuminen}

yleensä avun yhteisen työskentelyn kautta kehittyvä yhteinen kieli. Prosessit eivät todellisuudessa tottele mitään jaotteluja, vaan niiden eri elementit esiintyvät sisäkkäin ja päällekkäin. Jaottelut auttavat kuitenkin jäsentämisen kautta saamaan otetta kehitettävään organisaatioon. Yksinkertaiset ratkaisut eivät voi kuitenkaan toimia monimutkaisessa ympäristössä. Kompleksisuus ja tilannetta vastaavat resurssit ovat vaikea yhdistelmä. Sen tähden työskentelyn rajaaminen liian kapealle alueelle ja muiden näkökohtien huomiotta jättäminen voi estää tavoiteltujen muutosten ja tulosten toteutumista. Muutoksissa täytyy olla myös joustavuutta ja variaatioita.

$\mathrm{O}$ nnistunut kehittämisprosessi edellyttää kunnollista muutossuunnitelmaa, vahvaa toteuttamisverkostoa ja onnistunutta yhteistyötä. Työprossien uudistamiseen liittyvä teknis-taloudellinen fokus vaatii tuekseen käyttäytymistasoisen yksilöllisen ja yhteisöllisen dynamiikan huomioonottamista. Irralliset kehittämisponnistukset ovat yleensä jääneet tuloksiltaan vaatimattomiksi. Riit- tävä ymmärrys organisaation tehtäviin ja koko organisaatioon kytkeytyvistä juridisista ja poliittisistakin ulottuvuuksista voi olla tarpeellista ja edellyttää myös ulkopuolisia haastatteluja aineiston keruun aikana näkemyksen kehittämiseksi ja “systeemiymmärryksen" lisäämiseksi.

Kokemus on osoittanut, että organisaation luonteen ja sen omaehtoisten vahvuuksien arvostaminen on aina tärkeää minkä tahansa intervention onnistumiselle. Sen tähden onnistuminen ja menestys

- alkaa itsetiedostuksesta

- kasvaa sisältä ulos

- kumpuaa oivalluksesta, ei matkimisesta

- kehittyy organisaation vahvuuksille rakenta malla.

\section{IRRALLISESTA KEHITTÄMISESTÄ SYSTEEMISEEN YMMÄRTÄMISEEN}

Edellä on viitattu siihen, millaisia rajoituksia me- 
kanistiseen, eri syistä yksinkertaistettuun ja pääasiallisesti vain tehokkuuden lisäämiseen tähtääviin kehittämispyrkimyksiin voi liittyä. Yksi ilmeinen syy odotettua vähäisempiin onnistumisiin näyttää olleen prosessien "kolmiyhteisen" luonteen (prosessi, sisältö, konteksti) liiallinen redusoiminen ja yksipuolistaminen, jolloin tavoiteltuja pysyviä hyötyvaikutuksia ei olekaan saavutettu. Prosessien kehittämisen retoriikka on myynyt hyvin ja luvannut ehkä liikaa ja liian helpolla.

$\mathrm{K}$ ritiikin voimakkain kärki on suuntautunut prosessijohtamisen nimellä tunnettuun "koulukuntaan", jonka piiriin kuuluu useita hieman eri tavoin painottuneita kehittämismenetelmiä. Näitä yhdistävänä piirteenä on nähty pyrkimys työn organisoinnin kehittämiseen asiakaslähtöisesti ja uuden informaatioteknologian aikaisempaa parempaan hyödyntämiseen tehokkaan ohjausvaikutuksen aikaansaamiseksi ja ylläpitämiseksi. Arvostelun lähtökohtana ovat olleet ensisijaisesti menettelytapojen lähtökohdat ja tavoitteet ja niiden reaalisia ilmiöitä yksinkertaistaviin synteeseihin pyrkivä luonne.

Konteksteistaan irroitetut kehittämistoimet ovat jääneet usein liian irrallisiksi eivätkä oletetut synteesitkään ole toimineet. Prosessien holistisempi erittely edellyttää "systeemistä ymmärrystä”, jossa useat eri näkökulmat pyritään ottamaan yhtäaikaisesti huomioon. Kysymys on paljolti toisiinsa vaikuttavien ja toisistaan riippuvaisten menettelyjen ja toimintatapojen yhteensovittamisesta. Muutokset eivät useimmiten etene lineaarisesti taloudellisen tai teknisen rationaliteetin mukaan, vaan niihin vaikuttaa aina myös yhteisöllinen ja käyttäytymistasoinen dynamiikka.

Kehittämistyössä toimiviin konsultteihin kohdistuvat vaatimukset ovat siten suuret. Heidän tulisi pystyä paitsi prosessien holistiseen erittelyyn myös rakentamaan toimiva yhteistyösuhde asiakasjärjestelmään. Konsulttien ongelmana ei niinkään ole spesifin substanssiosaamisen puute kuin yhteistyösuhteessa ilmenevät pulmat (hänen tulisi olla asiantuntija myös siinä, miten hyvä yhteistyösuhde rakennetaan!) ja vaikeus ymmärtää organisaation systeemistä kokonaisuutta. Konsultti on monesti oman taustansa ja paradigmansa rajoittama asiantuntija.

$\mathrm{P}$ rosessikonsultoinnin nimellä tunnettu lähestymistapa korostaa asiantuntijan ja konsultin työskentelytavan erilaista painotusta. Sen mukaan keskeistä on, että konsultti auttaa asiakasta auttamaan itse itseään ja että yhteistyön tuloksena asiakkaan edellytykset ratkaista omia kehittämisongelmiaan ovat parantuneet. Konsultin tehtävä on eräässä mielessä tehdä itsensä tarpeettomaksi. Tämä on usein myös tie kestäviin muutoksiin.

Käytännössä asiantuntijan ja konsultin roolit voivat vaihdella yhteistyön kestäessä, mutta pyrkimyksenä on yleensä asiantuntijapanoksen vähentäminen yhteistyön edetessä. Konsultin interventioiden tulisi aina perustua validiin ja riittävän monipuoliseen informaatioon, ylläpitää ja vahvistaa asiakasjärjestelmän valinnan vapautta ja autonomiaa sekä tukea asiakasjärjestelmän sitoutumista niihin valintohin, joita se tekee.

\section{LÄHDELUETTELO}

ALASOINI, T. (1998). Työelämän kehittämistoiminnan rooli ja mahdollisuudet työllisyyden edistäjänä edistävätkö uudet työn organisaatiomuodot työllisyyttä ? Kansallinen työelämän kehittämisohjelman työpapereita 6. Helsinki.

BARLETT, C. \& Ghosal, S.(1989). Managing Across Borders: The Transnational Solution. Harvard Business School Press. Boston.

COLLINS, J. C. \& Porras, J. I. (1994). Built to Last: Successful Habits of Visionary Companies. Harper Collins. New York.

FINSTAD, N. The Rhetoric of Organizational Change Human Relations 51 (1998): 6, 717-740.

GERSICK, C. J. G. Revolutionary Change Theories: A Multilevel Exploration of the Punctuated Equilibrium Paradigm. Academy of Management Review, 16 (1991): 1, 10-36.

GRINT, K. \& Case, P.: The Violent Rhetoric of Re-engineering: Management Consultancy on the Offensive. Journal of Management Studies, 35 (1998), 5 , 557-577.

HAMEL, G. \& Prahalad, C. K. (1994). Competing for the Future. Harvard Business School Press. Boston

HANNUS, J. (1994). Prosessijohtaminen: ydinprosessien uudistaminen ja yrityksen suorituskyky. 4. painos. HM \& V Research. Jyväskylä.

HAMMER, M. \& Champy, J. (1993). Reengineering the Corporation: A Manifesto for Business Revolution. HarperBusiness. New York.

HASSARD, J. Aspects of Time in Organization. Human Relations, 44 (1991), 105-125. 
HIRSCHHORN, L. (1990). The Workplace Within. MIT Press. London.

HUBER, G. P. Organizational Learning: The Contributing Processes and Literatures. Organization Science, 2 (1991), 1, 88-115.

LEVITT, B. \& March, J.G. Organizational Learning. Annual Review of Sociology, 14 (1988), 319-340.

MARSHAK, R. J. Managing the Methaphors of Change. Organizational Dynamics, Winter 1993, 44-56.

MICKLETHWAIT, J. \& Woolridge, A. (1996). The Witch Doctors: Making Sense of the Management Gurus. Random House. New York.

MONGE, P. R.: Theoretical and Analytical Issues in Studying Organizational Processes. Organization Science, 1 (1990), 4, 408-426.

MUMFORD, E. (1997). Assisting work restructuring in complex and volatile situations. In J. E. Neumann, K. Kellner and A. Dawson-Sheperd (Eds.), Developing Organisational Consultancy. Routledge. Printed in Great Britain.

PETTIGREW, A. M. What is a processual analysis ? Scandinavian Journal of Management, 13 (1997), 4, 337 348.

PORTER, M. (1996). What is strategy ? Harvard Business Review, November-December 1996, 61-78.

S.A.M.I. Ernst \& Young (1998). Vuosikirja 1999: Liike toiminta - prosessi. Helsinki.
SCHEIN, E.H. (1969). Process Consultation: Its Role in Organization Development. Addison-Wesley. Printed in the U.S.A..

SCHEIN, E. H.: (1987). Process Consultation, Volume II. Lessons for Managers and Consultants. AddisonWesley. Printed in the U.S.A..

SCHNEIDER, W. E. (1997). Aligning strategy, culture and leadership. In J.E. Neumann, K. Kellner and A. Dawson-Sheperd (Eds.), Developing Organisational Consultancy. Routledge. Printed in Great Britain.

STEELE, F. (1975). Consulting for Organizational Change. University of Massachusetts Press. Printed in the U.S.A.

SZTOMKA, P. 1991). Society in Action: The Theory of Social Becoming. University of Chicago Press. Chicago.

TICHY, N. M. (1983). Managing Strategic Change. Technical, Political and Cultural Dynamics. John Wiley \& Sons. Printed in the U.S.A..

TIKKANEN, H. (1998). The Process Movement. A Critical Review. Liiketaloudellinen Aikakauskirja 2/ 1998, 204-226.

Artikkeli saapui toimitukseen 1.2.1999. se hyväksyttiin julkaistavaksi 15.2.1999. 